\title{
A ESPERANÇA CRISTÃ NA "TEOLOGIA DA ESPERANÇA": 45 anos da Teologia da Esperança de Jürgen Moltmann: sua história, seu caminho, sua esperança
}

\section{The christian hope in the "Theology of Hope": 45 years from the Theology of Hope by Jürgen Moltmann: its history, its way, its hope}

\section{Cesar Augusto Kuzma}

Doutorando em Teologia pela Pontifícia Universidade Católica do Rio e Janeiro (PUC-Rio), Professor de Teologia sistemática e Teologia pastoral na Pontifícia Universidade Católica do Paraná (PUCPR), Diretor do curso de Bacharelado em Teologia na PUCPR, Curitiba, PR Brasil, e-mail: cesar.kuzma@pucpr.br

\section{Resumo}

A esperança cristã na “Teologia da Esperança”. O artigo traz uma reflexão teológica dos 45 anos da Teologia da Esperança de Jürgen Moltmann. Apontaremos principalmente para a esperança cristã que se situa dentro deste contexto. Para isso, descreveremos sua história, seu caminho e sua esperança. Jürgen Moltmann é um dos maiores teólogos cristãos da 
atualidade. Em suas obras, traz um novo enfoque à escatologia, destacando a realização da esperança escatológica através da justiça, da humanização do ser humano, da socialização da humanidade e da paz para toda a criação. Para ele, falar de esperança é falar de uma força positiva que nos faz caminhar rumo a um novo horizonte. É algo supremo, intocável, infinito. Este trabalho de pesquisa está divido em três partes: a primeira parte trará uma reflexão sobre a obra e seu contexto - sua história; a segunda parte apresenta o seguinte enfoque: meditando a esperança na Teologia da Esperança - seu caminho; na terceira e última parte discorreremos sobre a Teologia da Esperança e os seus 45 anos - sua esperança.

Palavras-chave: Esperança cristã. Teologia da Esperança. Jürgen Moltmann. 45 anos.

\section{Abstract}

The Christian hope in the "Theology of Hope". The article brings a theological reflection of the 45 years from the Theology of Hope by Jürgen Moltmann. We will show mainly to the Christian hope that is situated in this context. For this we will describe its history, its way and its hope. Jürgen Moltmann is one of the most important Christian theologians in nowadays. In his works, he brings a new focus to the eschatology, bringing up the realization of eschatological hope through justice, humanization of the human being, socialization of humanity and peace to all creation. For him, to speak of hope is to speak of a positive strength that makes us walk towards a new horizon. It's something supreme, untouchable, infinite. This research is divided in three parts: the first part will bring a reflection about the work and its context - its history; the second part shows the follow focus: meditating the hope in the Theology of Hope - its way; in the third and last part we will discourse about the Theology of Hope and the its 45 years - its hope.

Keywords: Christian hope. Theology of Hope. Jürgen Moltmann. 45 years. 


\section{Introdução}

Falar da esperança cristã na Teologia da Esperança (Theologie der Hoffnung) é falar a partir de uma obra que surgiu em 1964 e que ainda hoje se mostra atual, apresentando-se com um caminhar próprio em cada lugar onde é apresentada. ${ }^{1}$ Ela foi também um ponto de partida para o movimento teológico, com o mesmo nome que surgiu nos anos sessenta do século XX. ${ }^{2}$ Para Jürgen Moltmann, esta obra - Teologia da Esperança - aparece como uma aventura sempre nova, disposta a trilhar novos caminhos e a abrir novos horizontes. A motivação de escrever sobre os seus 45 anos vem da importância que esta obra tem para a teologia contemporânea e, também do profícuo diálogo que teve com a teologia latinoamericana (Teologia da Libertação). Outro ponto que nos motiva à pesquisa é o fato de o próprio autor ter vindo ao Brasil em 2008 para deixar o seu "testamento" para a América Latina. Para tanto, nosso artigo tratará do contexto em que surge esta obra e os seus principais fundamentos, o que nos mostrará a sua história. Veremos também o seu caminho e também a sua esperança, ou seja, como que esta teologia pretende dialogar com a sociedade atual e trazer o sentido que lhe é própria.

\section{A obra e seu contexto - sua história}

Antes de falar de sua obra necessitamos apresentar um pouco do autor, Jürgen Moltmann, que é por excelência o grande responsável por este feito. Jürgen Moltmann é um dos teólogos mais respeitados e influentes do mundo contemporâneo, possui uma teologia expressiva. Como ressalta Battista Mondin (2003), talvez seja a figura mais representativa da teologia protestante contemporânea, depois de grandes líderes anteriores como Barth, Cullmann,

1 Para o presente artigo nós utilizaremos a tradução recente feita por Helmuth Alfredo Simon, que está na $3^{\text {a }}$ edição pelas Editoras Teológica e Loyola (MOLTMANN, 2005), consultando conjuntamente a obra em sua escrita original no alemão: MOLTMANN, 1968 [1964].

2 Sobre o movimento teológico da Teologia da Esperança, que se tornou referência para a teologia contemporânea, podemos encontrar maiores informações nas seguintes obras, além de excelente fundamentação: MONDIN, 1979, p. 69-100; MONDIN, 2003, p. 283-303; GIBELLINI, 1998, p. 279-299; GIBELLINI, 1975; MOLTMANN, 1978; p. 63-123; MARSCH, 1972. Além de outras obras do próprio autor em destaque que procuram retratar aspectos significativos desta teologia.

Rev. Pistis Prax., Teol. Pastor., Curitiba, v. 1, n. 2, p. 443-467, jul./dez. 2009 
Tillich e Bonhoeffer (MONDIN, 2003, p. 283). É de confissão cristã reformada, nascido em 18 de abril de 1926 na cidade de Hamburgo, Alemanha. Logo cedo, aos dezessete anos, após ver a sua cidade destruída em julho de 1943 e, também, por ser soldado recém-incorporado, foi convocado para o front do exército alemão, no qual, depois de seis meses, foi feito prisioneiro e levado ao campo de concentração de Northon Camp, na Inglaterra.

Dentre os prisioneiros deste campo destacavam-se alguns professores de teologia, através dos quais, depois de forte experiência, teve a possibilidade de iniciar seus estudos teológicos, cujas esperanças foram se manifestando e se construindo. Já em 1948 voltou à Alemanha e decidiu por prosseguir seus estudos em Göttingen até 1952, ano em que os concluiu. Academicamente, ensinou História dos Dogmas e Teologia Sistemática na Kirchiliche Hochschule de Wuppertal, onde foi colega de Wolfhart Pannenberg. Ali permaneceu de 1958 até 1963, ano em que foi chamado para a Universidade de Bonn. Mais tarde, desde 1967, tornou-se professor na Universidade de Tübingen, da qual hoje permanece como professor emérito. Também no período de 1967-1968 foi convidado na condição de professor visitante a Duke University, EUA. Jürgen Moltmann é casado com Elizabeth Moltmann-Wendel, também doutora em teologia, escritora e professora. Eles têm quatro filhos.

É considerado o fundador da Teologia da Esperança, movimento teológico contemporâneo que surgiu na Alemanha durante a segunda metade do século XX e, também, o seu principal expoente. Este movimento se caracteriza por várias expressões, em várias partes onde éapresentado e interpretado. Uma expressão teológica, decorrente deste movimento, que é atribuída a Moltmann também é a Teologia da Cruz, desenvolvida em período posterior, assim como a Teologia Política que, juntamente com J. B. Metz se tornou uma expressão teológica de grande repercussão.

O ponto inicial de sua carreira teológica e que marca a sua ligação com a corrente teológica citada acima é com a publicação de sua obra Teologia da Esperança (Theologie der Hoffnung), em 1964. Nela, o tema da esperança aparece como elemento hermenêutico, levando-a, assim, ao centro da teologia, conforme suas palavras: "já não mais teorizava sobre a esperança, mas a partir dela" (MOLTMANN, 1991, p. 170). Ou também: "O todo da teologia em um único enfoque” (MOLTMANN, 2005, p. 24). É um teólogo que possui uma grande aceitação no meio católico, pelo seu comportamento ecumênico e possui um importante diálogo com a Teologia da Libertação. ${ }^{3}$

3 Ver também MOLTMANN, 1998.

Rev. Pistis Prax., Teol. Pastor., Curitiba, v. 1, n. 2, p. 443-467, jul./dez. 2009 
Ao escrever o prefácio para os 33 anos de sua obra, em maio de 1997, Moltmann descreve isso como "algo arriscado", pois, para ele, os livros também têm um tempo bem próprio, seguem um caminho só deles.

É o que ocorreu com a Teologia da esperança. Eu a publiquei em 1964. Em 1967, foi lançada a tradução inglesa. Depois disso, porém, ela escapou ao meu controle e fez sua própria história; uma história que eu não havia pretendido nem previsto, mas que reverteu para mim de muitas formas diferentes. Eu sou o autor do livro, reconheço e sustento tudo o que escrevi naquela época. No entanto, algo bem diferente é a história que foi influenciada pela Teologia da esperança. Nela eu sou apenas uma pessoa entre tantas outras. Nela, sou apenas o primeiro leitor do livro mais do que seu autor. (MOLTMANN, 2005, p. 19).

Ao dizer isso, Moltmann nos insere dentro do contexto de sua obra. Como ele mesmo diz, ele não é apenas o único autor, mas como todos os leitores, ele foi influenciado por ela. Em algumas vezes, durante os anos que se seguiram pós-obra, ele mudou de posturas em relação à esperança, fato que ocorreu pelo retorno que sua obra lhe trouxe quando entrou em contato com outros horizontes e com outras visões hodiernas da teologia. Por estas visões hodiernas da teologia entendemos os movimentos e correntes teológicas que o autor manteve diálogo ao longo de sua vida, conforme ele mesmo destaca várias vezes: a Teologia da Libertação, a Teologia Política, a Teologia Negra, a Teologia Feminista, etc. Sem falar das constantes mudanças no cenário político mundial, que provoca, por parte da Igreja e por parte da teologia, uma postura de atitude concreta. Sobre essas questões, ele as descreve como algo positivo, o que demonstra uma teologia aberta aos novos descobrimentos, além de um constante diálogo com o mundo contemporâneo.

Ao querer resgatar a origem desta obra, verificamos que a esperança sempre fez parte da vida do autor, sobretudo no período de guerra e pós-guerra (KUZMA, 2008, p. 14-20). No entanto, o surgimento da Teologia da Esperança, de maneira mais sistemática, ocorre entre os anos de 1958 e 1964, quando se discutia entre os editores do periódico Evangelische Theologie as controvérsias existentes entre a Teologia do Antigo Testamento, de Gerhard von Rad e, a Teologia do Novo Testamento, de Rudolf Bultmann, com o objetivo de chegar a uma teologia sistemática que fosse biblicamente fundamentada. A questão

Rev. Pistis Prax., Teol. Pastor., Curitiba, v. 1, n. 2, p. 443-467, jul./dez. 2009 
central da discussão era a compreensão da história. ${ }^{4}$ “O que estava em jogo era nada menos do que a superação do existencialismo generalizado do período pós-guerra, visando à obtenção de perspectivas de futuro para um mundo mais justo, mais pacífico e mais humano” (MOLTMANN, 2005, p. 20).

Este é um momento em que se volta a discutir as promessas de Deus dentro de um horizonte judeu-cristão, no qual Moltmann se vê influenciado pela filosofia de Ernst Bloch com a obra O Princípio Esperança (Das Prinzip Hoffnung), de 1959. ${ }^{5}$ Perguntava-se, pois, de que modo a história representava um todo e de que maneira as promessas de Deus despertavam esperanças humanas? Com isso, a reflexão teológica se direciona para o sentido do êxodo de Israel e, também, a compreensão de Reino de Deus passa a ganhar um sentido de orientação para o futuro, totalmente escatológico. Assim, a base e o motivo da esperança se encontram no êxodo e na ressurreição de Cristo (MOLTMANN, 2005, p. 20-21).

Porém, neste instante, faz-se necessário perguntar: como era a situação à qual nos referimos e que fez surgir então a Teologia da Esperança? Sobre isso nos utilizaremos de trechos do próprio autor, pelos quais nos descreve aspectos importantes de seu contexto histórico:

Em 1964, a Teologia da esperança, evidentemente, ainda que não intencionalmente, acertou o seu kairós. O tema, por assim dizer, estava no ar. No Concílio Vaticano II, a Igreja Católica Romana estava mesmo

4 Essa busca pela compreensão da história fez com que o autor disponibilizasse parte de sua obra para confrontá-la com as promessas de Deus. O Deus da esperança, apresentado por ele, é um Deus que se insere na história, que se faz história, que a assume e a transforma. Na Teologia da Esperança encontramos um bom ensaio que retrata as promessas feitas por Deus na história de Israel no capítulo II, mas ela é estudada com mais magnitude no capítulo IV de sua obra. Vale destacarmos também que esta insistência pela história perpassa toda a sua teologia, desde a discussão para esta obra até as suas obras mais recentes. Em visita à Universidade Metodista em outubro de 2008 - eu tive a honra e o privilégio de participar de uma audiência com ele perguntaram sobre os principais livros de sua vida; ele, seguro de si, respondeu: em primeiro lugar a Bíblia, especialmente o Antigo Testamento, pela história da promessa de Deus e o encontro deste na história da humanidade, culminando no Novo Testamento; em segundo lugar a obra de Ernst Bloch, O Princípio Esperança (Das Prinzip Hoffnung), uma obra motivadora de sua teologia; e em terceiro lugar a Dogmática Cristã de Karl Barth.

5 Eis um ponto muito influente em Moltmann, que já tinha feito um debate com Ernst Bloch em 1963 - um ano antes da Teologia da Esperança, publicado também como apêndice nesta obra: "O Princípio Esperança e a Teologia da Esperança - um diálogo com Ernst Bloch."

Rev. Pistis Prax., Teol. Pastor., Curitiba, v. 1, n. 2, p. 443-467, jul./dez. 2009 
se abrindo para as questões do mundo moderno. Nos Estados Unidos da América, o Movimento pelos Direitos Civis teve os seus pontos altos na luta contra o racismo. Na Europa oriental, assistimos ao surgimento de um marxismo reformista, que em Praga foi chamado de "socialismo da face humana”. Na América Latina, a revolução bem sucedida em Cuba despertou, em toda parte, as esperanças dos pobres e dos intelectuais. $\mathrm{Na}$ Alemanha Ocidental, superamos a estagnação do período pós-guerra com a bandeira: "Nada de experimentos!", por meio da vontade de ter "mais democracia" e uma justiça social melhor e por meio da "luta contra a morte atômica". Os anos sessenta realmente foram anos de pôr-se em marcha e de voltar-se para o futuro, anos do renascimento das esperanças. (MOLTMANN, 2005, p. 21-22).

Percebemos aqui que o contexto era propício para tal formulação, uma vez que, como diz o autor, o tema da esperança “estava no ar”. Um aspecto positivo que ele destaca é sobre a abertura da Igreja Católica. Isso resulta dos reflexos provocados pelo Concílio Vaticano II (1962-1965), sobretudo pela sua Constituição Gaudium et spes, que como o próprio nome diz trata sobre as alegrias e as esperanças que germinam do coração da Igreja. É um documento totalmente voltado para a ação da Igreja no mundo, sua missio. Ele também enumera outras situações em que a esperança motivou forças e abriu novos caminhos. Mas, segundo Moltmann, esse kairós ao qual se refere no início dos anos 60 e que, como ele relatou antes, suscitou tantas esperanças, não permaneceu de maneira completa ao seu final. De imediato, por ordens diversas, o mundo é cercado por frustrações, como ele mesmo relata:

Contudo, os anos sessenta terminaram com frustrações amargas em relação às referidas esperanças: no outono de 1968, em Praga, os tanques e as tropas do Pacto de Varsóvia demoliram o "socialismo de face humana”. A guerra do Vietnã fez com que os EUA entrassem em um conflito trágico consigo mesmos. Em 1968, foi publicada a Encíclica Humanae vitae que pôs um fim à abertura da Igreja Católica para o mundo de hoje. No mesmo ano, as esperanças ecumênicas atingiram seu ponto alto na Conferência Mundial das Igrejas em Uppsala, com o lema: "Eis que faço nova todas as coisas!”, entrando em seguida em conflito com os evangélicos e conservadores. A crise econômica de 1972 - a crise do petróleo - deixou claro para todos que não vivemos na "terra das possibilidades irrestritas" e que o futuro tampouco é ilimitado, mas que temos que contentar-nos com esta terra e seus recursos limitados. Em

Rev. Pistis Prax., Teol. Pastor., Curitiba, v. 1, n. 2, p. 443-467, jul./dez. 2009 
vista disso, para muitos, a esperança de um futuro melhor reverteu em resistência ativa contra as destruições reais da vida neste planeta. A grande esperança, que naquela época, porém, ainda era de cunho muito geral, tornou-se concreta em muitas ações pequenas e restritas: nos movimentos ecológicos, no movimento pela paz, no movimento feminista e em outros movimentos. (MOLTMANN, 2005, p. 22).

Evidentemente que não foram períodos marcados apenas por frustrações, pois vale destacar aqui que, para a Igreja Católica da América Latina, o ano de 1968 passou a ser um marco referencial histórico com a Conferência Episcopal de Medellín. Nela se levantou a bandeira da Igreja em favor dos pobres e com um caráter totalmente libertador. Foi um momento de esperança que atingiu todo o continente. Contudo, não se anula o que foi mencionado por ele sobre o impacto que se teve com a Encíclica Humanae vitae do mesmo ano. Mas, para o seu contexto, basicamente europeu, todas essas frustrações começam a terminar exatamente vinte anos depois, quando, a partir de 1989, surgem sinais e milagres, os quais, segundo o autor, ninguém mais esperava. Esses supostos sinais e milagres que o autor deduz tratam-se especificamente de mudanças na política mundial: A queda do regime soviético, o fim do apartheid na África do Sul, mudanças de paradigmas políticos mundiais, entre outros. (MOLTMANN, 2005, p. 23). Por pertencer à história, a esperança abre novos caminhos e redireciona novamente a própria história.

Além disso, neste momento, sua obra e teologia percorrem parte do mundo, deixando nesses lugares a sua influência. Essa influência o autor não a assume como pessoal, mas como estritamente da obra, que fez um caminho próprio, como já foi detalhado aqui e ele mesmo disse tempos atrás no prefácio da terceira edição em 1977. Ali o autor afirma que este livro fez o seu próprio caminho pelo mundo: “A Teologia da esperança foi discutida em numerosos periódicos teológicos e não teológicos, cristãos e não cristãos. Ela deu sua contribuição para que o labor teológico se orientasse para a história do Deus da esperança” (MOLTMANN, 2005, p. 27).

Nesta influência da Teologia da Esperança em outras teologias, o autor diz que tal experiência retornou para ele de modo diferente, o que contribuiu para que tivesse uma abertura maior dentro do horizonte teológico. Em muitos lugares em que a Teologia da Esperança foi apresentada, sua esperança foi traduzida por ação, pelo fato de sua efetividade se confrontar com o contexto atual. Sobre o que fez surgir esta influência ele supõe duas hipóteses:

Rev. Pistis Prax., Teol. Pastor., Curitiba, v. 1, n. 2, p. 443-467, jul./dez. 2009 
primeiramente, a perspectiva coerente da libertação histórica e, depois, a redenção escatológica que dela provém (MOLTMANN, 2005, p. 23).

Sobre as críticas que recebeu de sua obra, por muitas vezes, elas serviram de abertura ao diálogo teológico e ele nunca as viu como problema, nem mesmo quando o acusaram de ter uma visão unilateral. Aliás, como ele mesmo relata, essa foi a crítica mais frequente a respeito de seus primeiros livros. Todavia, isso não o assusta, ao contrário, o honra e vem confirmar aquilo que foi dito. Para ele, "quem toma a palavra em uma discussão importante e estimulante, quando quer alcançar alguma coisa, sempre se torna unilateral” (MOLTMANN, 2005, p. 24). A teologia não tem e nunca terá uma visão total de Deus e de seu mistério, ela parte antes de uma experiência de fé, logo toda ela é unilateral, ou seja, imperfeita.

Com efeito, após identificarmos o que provocou a origem desta obra, propomo-nos, a partir de agora, meditar com o autor sobre o que concerne a sua esperança.

\section{Meditando a esperança na Teologia da Esperança - seu caminho}

Moltmann inicia a sua obra - Theologie der Hoffnung - meditando sobre a esperança (Meditation über die Hoffnung). Trata-se de uma introdução (Einleitung) na qual ele questiona, inicialmente, sobre o lugar que ocupa a escatologia cristã (christliche Eschatologie) na reflexão teológica de seu tempo. Para ele, ela não pode mais ser direcionada apenas ao final, como era apresentada no passado, como um apêndice da teologia. Ela deve envolver o todo, pois faz parte do todo. Vejamos isso com suas palavras:

Na realidade, a escatologia é idêntica à doutrina da esperança cristã, que abrange tanto aquilo que se espera como o ato de esperar, suscitado por esse objeto. O cristianismo é total e visceralmente escatologia, e não só como apêndice; ele é perspectiva, e tendência para frente, e, por isso mesmo, renovação, e transformação do presente. O escatológico não é algo que se adiciona ao cristianismo, mas é simplesmente o meio em que se move a fé cristã, aquilo que dá o tom a tudo que há nele, as cores da aurora de um novo dia esperado que tingem tudo o que existe. De fato, a fé cristã vive da ressurreição do Cristo crucificado e se estende em direção às promessas do retorno universal e glorioso de Cristo. Escatologia é "paixão" em dois 
sentidos, o de sofrimento e o de tendência apaixonada, que têm sua fonte no Messias. Por isso mesmo, a escatologia não pode ser simplesmente parte da doutrina cristã. Ao contrário, toda pregação e mensagem cristãs têm uma orientação escatológica, a qual é também essencial à existência cristã e à totalidade da igreja. (MOLTMANN, 2005, p. 30).

Ao comparar esta mesma passagem Hans-Georg Geyer (1972, p. 41-81), que fez uma relevante discussão desta obra, indicará que Moltmann nos apresenta nesta introdução três teses básicas de sua teologia: 1) O Cristianismo é escatologia do princípio ao fim; 2) O fundamento cristológico da escatologia cristã: a fé cristã vive da ressurreição de Cristo; 3) O problema do futuro. Se olharmos novamente para o texto acima poderemos verificar facilmente estas três teses totalmente sobrepostas. E, também, com um olhar mais atento para toda a obra, observamos que nestas três teses resume-se o objetivo principal de sua reflexão. Gibellini (1975, p. 80) chama a isso de Teorema da Teologia da Esperança.

No fundo, Moltmann quer afirmar que toda a essência desta escatologia encontra-se na definição de esperança. É uma esperança que interage no meio em que está; é dinâmica e ao mesmo tempo crítica da realidade. Por se fundamentar no Cristo ressuscitado como alicerce intransponível da fé, ela se projeta totalmente ao futuro, mas de maneira bem enraizada nas promessas do passado. Ela não serve como fuga da história, mas como orientação à sua existência. Essa nova compreensão de escatologia, que o autor nos traz, "implicase na realidade histórica a ponto de transformá-la” (TAMAYO, 1999, p. 223).

Para Moltmann, todo o conteúdo da verdade cristã possui uma orientação escatológica. Somos movidos pela esperança, pelo ato de esperar (hoffen). A verdade cristã está totalmente projetada para o futuro e anseia por ele, portanto, toda a teologia é escatologia. A partir deste enfoque, o único problema que existe na teologia cristã, segundo nosso autor, diz respeito ao seu futuro (das Problem der Zukunft). Este futuro apresenta-se como um Outro (das Andere), ${ }^{6}$ o qual, a partir de nossas experiências, nós não podemos nem ousar pensar, pois ele está além daquilo que nos é dado. Transcende sempre como algo Novo (Neuen), portanto, o verdadeiro objeto da esperança cristã encontra-se definitivamente no futuro de Deus (als Hoffnung auf eine Zukunft aus Gott). “O Deus, de que aí se fala, não é o Deus intramundano ou extramundano, mas o ‘Deus da Esperança’” (MOLTMANN, 2005, p. 30).

6 O sentido em que é colocado o termo um Outro (das Andere) pelo autor, remete a um Outro novo, que traz novidade.

Rev. Pistis Prax., Teol. Pastor., Curitiba, v. 1, n. 2, p. 443-467, jul./dez. 2009 
Por essa razão que, para o nosso autor, a palavra escatologia (doutrina das coisas últimas) não é o termo mais apropriado para designar o futuro de Deus. Para ele este termo é falso, pois uma doutrina sobre as coisas últimas não pode existir. O termo escatologia remete teoricamente a um fim, porém, a partir do enfoque que é conferido pela esperança ela não é o seu fim (fim-fim), mas o seu princípio (fim-para).

No entanto, este futuro que o autor apresenta acima não é algo fácil de expressar racionalmente e, certamente, gera uma indagação: como a escatologia cristã pode falar do futuro? No que ela se fundamenta? Vale apontarmos aqui que as características da esperança cristã apresentadas no NT estão alicerçadas nas características da esperança do AT: esperar, confiar e perseverar (HOFFMANN, 1970, p. 82). Elas também podem ser utilizadas aqui, porém ganham um sentido mais amplo. Sendo assim, Moltmann, ao afirmar a escatologia como esperança, diz que, “ela toma seu ponto de partida em uma determinada realidade histórica e prediz o futuro da mesma, suas possibilidades futuras e sua eficácia futura” (MOLTMANN, 2005, p. 30. Grifos nossos.).

Essa determinada realidade histórica de que nos fala o autor é algo fundamental para compreender a esperança como novo enfoque da escatologia cristã. Com isso retornamos à discussão que assistia ao grupo teológico Evangelische Theologie, do qual Moltmann participava e, cuja discussão culminou com a publicação dessa respectiva obra. Essa nova visão que é proporcionada pela escatologia busca na história uma base forte de compreensão e de identificação. O nosso futuro é projetado na história e, mais que isso, se projeta para além da história. Trazendo para uma definição cristã: “A escatologia cristã fala de Jesus e de seu futuro. Conhece a realidade da ressurreição de Jesus e anuncia o futuro do ressuscitado” (MOLTMANN, 2005, p. 31-32).

Essas novas questões que foram suscitadas a partir da nova compreensão da escatologia dizem que, se o Cristo ressuscitado e crucificado tem um futuro, existe, por certo, algo Novo que podemos esperar. Com esta nova definição, a esperança cristã passará a se identificar com aquilo que aconteceu com Cristo e passará a ansiar para si mesma esse futuro. No entanto, o futuro de Cristo também apresenta certas contradições. Isso ocorre porque o futuro ainda não se apresenta de modo visível no presente, mas como um contraste. Porém, nesta nova compreensão, ela, a esperança cristã, não ilumina a realidade que aí está, mas a que virá (MOLTMANN, 2005, p. 32). Para 
Moltmann, “a contradição, em meio à qual a esperança coloca o ser humano frente à realidade de si mesmo e do mundo, é a contradição entre a ressurreição e a cruz” (MOLTMANN, 2005, p. 33).

Expliquemos melhor: ela coloca o ser humano numa contradição entre o real e o que não consegue ser visto como real, entre o visível e o invisível. Isto se identifica na contradição existente entre a cruz e a ressurreição, que só é exprimível pela fé. Para tal posição, ele se fundamenta em Calvino, que reflete a partir de Hebreus (Hb 11,1) ${ }^{7}$ sobre a fé e a esperança e, por Moltmann ser da tradição cristã reformada, o pensamento calvinista exerce grande influência sobre a sua teologia. Segue abaixo o texto de Calvino:

É-nos prometida a vida eterna - a nós, que estamos mortos; é-nos anunciada uma feliz ressurreição, mas, enquanto isso, estamos cercados de corrupção; somos chamados justos e, não obstante, reside em nós o pecado; ouvimos falar de uma felicidade indivisível e, enquanto isso, somos aqui oprimidos por uma miséria sem fim; abundância de todos os bens nos é prometida, mas só somos ricos de fome e sede. O que seria de nós se não nos apoiássemos na esperança, e se nossos sentidos não se dirigissem para fora deste mundo, no caminho iluminado pela palavra e pelo Espírito de Deus em meio a essas trevas? (CALVINO apud MOLTMANN, 2005, p. 33).

Como demonstra no texto citado anteriormente, esta contradição entre a cruz e a ressurreição é uma constante da vida cristã. Isto reforça a tese de que o cristão vive neste mundo, mas com um olhar para além deste mundo (esperar), a ponto de, confiante (confiar) na esperança futura, decidir por transformar o presente. Seguindo o pensamento de Calvino citado acima: “O que seria de nós se não nos apoiássemos na esperança” (perseverar). Vemos aqui novamente as três características que apresentamos anteriormente muito bem representadas.

Utilizando-se deste texto de Calvino que destacamos acima, o qual ele cita em sua obra, Moltmann dirá que é na contradição que a esperança deve mostrar a sua força. Assim sendo, o verdadeiro significado da escatologia cristã é apresentar a esperança como fundamento e mola mestra de toda a teologia. Isto incidirá nas perspectivas que tratam a revelação de Deus, a ressurreição de Cristo, a missão da fé e a história (MOLTMANN, 2005, p. 34).

7 "A fé é garantia antecipada do que se espera, a prova de realidades que não se vêem" (Hb 11,1).

Rev. Pistis Prax., Teol. Pastor., Curitiba, v. 1, n. 2, p. 443-467, jul./dez. 2009 
Mas, como a esperança pode ganhar um sentido mais amplo? Seguindo o pensamento de Calvino, ele afirma que, a fé se apoia na esperança e se lança para fora deste mundo. Não como fuga, mas como quem busca o futuro. Isto significa: “transpor fronteiras, transcender, estar em êxodo" (MOLTMANN, 2005, p. 34). Não se trata mais de uma espera passiva, mas de uma espera ativa, que decide por ir atrás daquilo que outrora fora prometido. Aqui consiste a diferença e amplitude do conceito. Do mesmo modo, também com base calvinista, Moltmann confirma: “A fé une o ser humano a Cristo, a esperança abre essa fé para o vasto futuro de Cristo. Por isso, a esperança é a 'companheira inseparável’ da fé” (MOLTMANN, 2005, p. 35). ${ }^{8}$ É somente por meio dela que o ser humano entra no caminho da verdadeira vida e, somente a esperança o conserva nesse caminho. Concluindo este raciocínio teológico: "A fé é o prius, mas a esperança detém o primado” (MOLTMANN, 2005, p. 35. Grifos do autor).

Na ótica de sua teologia, Cristo se torna o Éschaton, o fundamento teológico por excelência e, é Nele que se encontra toda a contradição. No evento da cruz e ressurreição encontramos o consolo, mas também o protesto. Por isso a fé aliada à esperança "não traz quietude, mas inquietude; não traz paciência, mas impaciência” (MOLTMANN, 2005, p. 36). Sabemos que o nosso futuro é o Cristo ressuscitado, mas vivemos numa constante contradição em meio à dor e o sofrimento do mundo. Moltmann até se utiliza de Agostinho refletindo a partir do coração inquieto (cor inquietum): "Fizeste-nos para Ti, e nosso coração inquieta-se, enquanto não repousar em Ti”. (Tu nos fecisti ad Te, et cor nostrum inquietum est, donec requiescat in Te). Para ele a esperança não acalma o cor inquietum, mas ela é, com toda certeza, esse cor inquietum:

8 Sobre essa relação entre a fé e a esperança é importante apresentarmos um outro texto de Calvino que trata de maneira poética e considerável esse tema: "Se faltar a esperança, por mais que falemos da fé de forma genial e eloquente, podemos estar certos de que não temos nenhuma! A esperança nada mais é do que a espera das coisas que, conforme a convicção da fé, foram por Deus realmente prometidas. Assim, a fé está convencida de que Deus é veraz; e a esperança espera que ele, a seu tempo, revele sua verdade; a fé tem certeza de que ele é nosso Pai, e a esperança espera que ele sempre se mostrará como tal a nós; a fé está persuadida de que nos é dada a vida eterna, a esperança espera que ela um dia nos será manifestada; a fé é o fundamento sobre o qual descansa a esperança, e a esperança alimenta e sustenta a fé. Ninguém pode esperar qualquer coisa de Deus, se antes não crer em suas promessas; mas, ao mesmo tempo, nossa fraca fé, para não desfalecer pelo cansaço, deve ser sustentada e conservada, a fim de que pacientemente esperemos e aguardemos. A esperança renova e vivifica a fé sempre de novo e cuida para que sempre de novo se levante mais forte; para perseverar até o fim" (CALVINO. Institutio, III2, p. 42 apud MOLTMANN, 2005, p. 35).

Rev. Pistis Prax., Teol. Pastor., Curitiba, v. 1, n. 2, p. 443-467, jul./dez. 2009 
Quem espera em Cristo não pode mais se contentar com a realidade dada, mas começa a sofrer devido a ela, começa a contradizê-la. Paz com Deus significa inimizade com o mundo, pois o aguilhão do futuro prometido arde implacavelmente na carne de todo presente não realizado. Se diante dos olhos tivéssemos só o que enxergamos, certamente nos satisfaríamos, por bem ou por mal, com as coisas presentes, tais como são. Mas o fato de não nos satisfazer, o fato de entre nós e as coisas da realidade não existir harmonia amigável é fruto de uma esperança inextinguível. Esta mantém o ser humano insatisfeito até o grande cumprimento de todas as promessas de Deus. Ela o mantém no status viatoris, naquela abertura para o mundo futuro, a qual, pelo fato de ter sido produzida pela promessa de Deus na ressurreição de Cristo, não pode cessar por nada, a não ser pelo cumprimento por parte do mesmo Deus. (MOLTMANN, 2005, p. 36-37. Grifos do autor).

Por essa razão que a inquietude faz parte da esperança cristã. Ela não se conforma com o que é apresentado quando este contradiz o que foi prometido. O cor inquietum, proporcionado pela esperança cristã, sai em busca do seu futuro e não se contenta enquanto não conseguir realizá-lo. É essa esperança confiante de transformação que torna, segundo Moltmann, a Igreja cristã inquieta diante da sociedade. Ela continua peregrina, pois vê naquilo que lhe é apresentado pela sociedade como permanente algo que para ela é temporário. ${ }^{9}$ Seu destino é o futuro, que ela ainda não vê, mas sente, pois confia no que foi prometido com a ressurreição de Cristo. A esperança faz com que essa comunidade viva de impulsos sempre novos e, através de sua ação encontre a sua verdade e testemunhe o futuro de Cristo (MOLTMANN, 2005, p. 37).

Mas, o próprio autor coloca nesta sua Meditation que a falta da esperança também existe no atual cristianismo e esta falta produz o desespero (sem esperança). Isto ocorre como resultado da liberdade humana que se vê dividida. É a dualidade presente no ser humano, já testemunhada por Paulo em sua missão ${ }^{10}$ e vivida também por Moltmann quando prisioneiro no campo de

9 Podemos encontrar neste trecho algo presente também na eclesiologia católica, sobretudo naquilo que foi apresentado no Concílio Vaticano II, pela Constituição Lumen gentium, ao tratar no capítulo VII sobre: "A índole escatológica da Igreja peregrina e sua união com a Igreja do céu". Ver VATICANO II. cap. VII, n. 48-51, 1998. Ver também MARTINI, 1972; BOFF, 2003, p. 9-31.

10 No caso de Paulo, trata-se do momento em que se vê diante desta dualidade: "Com efeito, não faço o bem que quero, mas pratico o mal que não quero" $(\mathrm{Rm} 7,19)$.

Rev. Pistis Prax., Teol. Pastor., Curitiba, v. 1, n. 2, p. 443-467, jul./dez. 2009 
concentração. ${ }^{11}$ Diante de certas situações nos defrontamos com duas posições: avançar e romper em direção ao futuro ou parar e fixar a nossa vida no passado. A esperança cristã, que aqui ele nos apresenta, utiliza-se do passado, mas como recordação das promessas e como impulso a um futuro. Moltmann nos diz que a falta desta ação transforma-se no pecado que mais ameaça a vida do crente: a omissão. "Não o mal que ele faz, mas o bem que deixa de fazer; não são as suas más ações que o acusam, mas as suas omissões. Elas o acusam de falta de esperança” (MOLTMANN, 2005, p. 38).

Se a esperança não trouxer essa inquietude, a esperança que se produz será uma falsa esperança e frustrará o ser humano já no seu presente. Isto ocorre ao se tornar prisioneiro de um passado sem qualquer projeção de futuro. Você lembra que viveu, mas esquece de viver; lembra que amou, mas esquece de amar. Ou de forma alienada, a pessoa espera que um dia tornar-se-á feliz, mas essa felicidade passa longe de sua vida cotidiana. Essa é uma falsa esperança, muito adaptada à elpis (esperança) dos gregos, mas certamente não é o que produz a esperança cristã. A esperança cristã não pode frustrar o ser humano no presente porque ela é a verdadeira felicidade do presente. Ela provoca o ser humano a viver intensamente a sua vida. Sua vida se projeta para o futuro do mundo, que se realiza juntamente com o futuro de Cristo.

Essa espera futura, colocada pela escatologia cristã como a Parusia, arranca-nos do tempo e nos arremessa rumo à eternidade. Quando isto acontece o ser humano começa a viver em harmonia já no seu presente, sua contemporaneidade se transforma em eternidade. Tudo aquilo que foi prometido, através da esperança cristã, abre-se como realidade histórica. O escatológico penetra na história e a transforma. Nesse momento, o amor que é filia, convertese em amor ágape; o que era desigual se torna igual; o que era distante se torna próximo. A esperança cristã chama a si aqueles que foram excluídos e abandonados, os fatigados e sobrecarregados, os rebaixados e atormentados, os famintos e moribundos, porque sabe que para esses existe a parusia e a realidade do Reino de Deus. "Pela esperança, o amor mede as possibilidades que lhe foram abertas na história. Pelo amor, a esperança tudo encaminha para as promessas de Deus” (MOLTMANN, 2005, p. 48-49). Aqui não temos apenas a fé e a esperança, mas as três virtudes teologais cristãs concomitantemente: fé, esperança e caridade.

11 Sobre esta experiência de Moltmann no campo de concentração, indicamos um de nossos artigos: KUZMA, 2008, p. 11-20.

Rev. Pistis Prax., Teol. Pastor., Curitiba, v. 1, n. 2, p. 443-467, jul./dez. 2009 
Assim, após meditarmos a esperança que fez o autor escrever sua célebre obra “Teologia da Esperança”, nós confirmamos que a escatologia cristã adquire um novo horizonte, um novo enfoque ao se enquadrar com a esperança cristã. E é justamente isso que Moltmann procura trazer de modo acentuado na sua obra Teologia da Esperança. Isso surge em seu momento histórico, portanto, é uma reflexão que parte antes de uma experiência pessoal, e que hoje, 45 anos após, continua sendo a raiz teológica de seu pensamento.

\section{A Teologia da Esperança e seus 45 anos - sua esperança}

Ao apresentar um breve estudo sobre a Teologia da Esperança WolfDieter Marsch, que teve a felicidade de ler a obra ainda como um manuscrito, diz: “Os livros têm os seus destinos” (MARSCH; MOLTMANN, 1972, p. 9). É uma frase latina pertinente de Terenciano Mauro (século III d.C. - Habent sua fata libelli), sobretudo para nós que queremos refletir a história, o caminho e a esperança que seu trabalho percorreu em 45 anos. Sem dúvida, alguns livros possuem a capacidade de conquistar um destino que muitas vezes não foi projetado pelo seu autor e, podemos dizer que, com a Teologia da Esperança isso ocorreu de fato.

Moltmann nunca teve a pretensão de percorrer um caminho novo. Segundo J. M. Jong, o que ele faz é uma reordenação da teologia, desde o ponto de vista da esperança (JONG, 1972, p. 34), na qual apresenta problemas teológicos específicos dentro de sua obra. Desse modo, a concepção da esperança cristã dentro da Teologia da Esperança e o que se suscitou consequentemente em seu pensamento ganha mais clarividência.

Vejamos como se desenvolve: O primeiro problema que é apresentado na sua obra trata a questão da escatologia. Ao refletir sobre a esperança cristã Moltmann se pergunta sobre a essência do cristianismo. Para isso ele parte do pressuposto que o cristianismo é escatologia do princípio ao fim. Para tal, ele precisa relacionar a escatologia com a revelação. Isto será desenvolvido por ele inicialmente no capítulo I, tendo como consequência o capítulo II que trata das promessas como fundamento desta esperança. Seu segundo problema parte do fundamento cristológico da escatologia cristã e é, sem dúvida, o ponto central da Teologia da Esperança, pois trata da ressurreição de Cristo e de todos nós, de maneira explícita no capítulo III. Aqui ele traz o Cristo ressuscitado como o crucificado e, para ele 
este é o tema central de toda a fé cristã. ${ }^{12} \mathrm{O}$ terceiro problema que será desenvolvido diz respeito à relação entre Deus e a história, bem fundamentado no capítulo IV. Por fim, servindo-se do capítulo V seu quarto problema, refere-se ao problema do futuro, destacando as consequências da escatologia cristã na sociedade: somos um povo em êxodo, comunidade do êxodo (Exodusgemeinde). Aqui se destacam aspectos pertinentes da modernidade e, no confronto disso, no intuito de lançar a obra também para um futuro ele perguntará: qual o papel da missio cristã, já que nossa esperança se sustenta numa promissio de futuro?

Tendo visto como se desenvolve a Teologia da Esperança, acreditamos que os primeiros capítulos tratam dos principais fundamentos de sua teologia, todavia, é na sociedade atual (capítulo V) que Moltmann destinará a missão de sua esperança, sua missio. A esperança cristã que nasce de sua teologia deve estar inserida no mundo, a fim de transformá-lo. Não pode ser vista como uma esperança de fuga, mas sim de enfrentamento. Não apenas destinada ao céu, mas também à terra, onde está fincada a cruz de Jesus: “assim na terra como no céu”. Eis um ponto que ele acentuou em sua visita ao Brasil em outubro de 2008 (MOLTMANN, 2008, p. 36).

Ou seja, a Igreja (comunidade dos que creem) permanece em constante caminho (êxodo) na sociedade atual. Esta é a sua missio. Moltmann procurou retratar aqui sobre a compreensão escatológica do cristianismo na sociedade moderna, confrontando o seu papel diante desse quadro. Por esta razão, parecenos oportuno iniciar com a missio, pois o real ponto de apoio para uma compreensão escatológica dentro da sociedade só pode partir deste conceito. Desde que esta missio tenha como marco fundante a fé, só assim será uma missio cristã.

12 Em 1972 Moltmann dá um passo a mais na sua reflexão teológica sobre o Crucificado ao aprofundar a teologia da cruz, na qual se aproxima ainda mais da Teologia da Libertação. Esta obra intitula-se "O Deus crucificado" (Der gekreuzigte Gott), infelizmente sem tradução para o português, apenas em espanhol (El Dios crucificado. Salamanca: Sigueme, 1977). Isto se torna um marco para o autor: No dia 16 de novembro de 1989 na Universidade Católica de El Salvador (San Salvador) foram assassinados de modo brutal seis jesuítas e duas mulheres (mãe e filha). Os assassinos queriam silenciar a voz crítica de Ignácio Ellacuria (então reitor da Universidade). O corpo do jesuíta Ramon Moreno foi levado pelos soldados até o quarto de Jon Sobrino (também apontado como um suposto alvo dos militares e que estava ausente naquele momento). Ao jogarem o corpo no chão do quarto, um livro caiu da prateleira e se banha no sangue do mártir, o livro era "El Dios crucificado". Até hoje este livro banhado em sangue se encontra em exposição como símbolo do martírio daqueles seis jesuítas e daquelas duas mulheres. Ver MOLTMANN, 1998, p. 26-27. Também MOLTMANN, 2008, p. 18; MOLTMANN, 2004, p. 187.

Rev. Pistis Prax., Teol. Pastor., Curitiba, v. 1, n. 2, p. 443-467, jul./dez. 2009 
Este é o ponto que se apoia o autor e também é onde se apoia a Igreja, que tem na sua missão diante do mundo (motivada pela fé, esperança e amor) a sua fundamentação. ${ }^{13}$ Entendemos assim que, a Igreja, portadora do Espírito de Cristo, tem algo a dizer ao mundo e isso atinge completamente as dimensões sociais, sejam elas políticas, familiares, ecológicas, morais, éticas, religiosas, etc.

Ele relata também o fato de que não há dentro da sociedade moderna um espaço reservado para um cultus privatus, como se tinha antigamente na Igreja. Hoje em dia, o cristianismo sustenta uma vocação pública, com o intuito de dizer ao mundo aquilo que é essencial na sua dimensão de ser. Na atualidade não se pode conceber uma imagem do cristianismo (ou mais especificamente da Igreja) que esteja totalmente apartada do mundo, como uma societas perfecta. O chamamento que se faz na atualidade e que o autor frisa demasiadamente é de se sentir incluído dentro da história real, a ponto de, estando com o olhar focado para o futuro, transformar de imediato a realidade presente. Para ele a visão que se deve ter de Igreja é sempre de base pneumatológica, ela nasce da força do Espírito, como retrata a sua obra a "Igreja na força do Espírito" (Kirche in der Kraft des Geistes): ${ }^{14}$ "[...] a Igreja é o que é na medida em que está na presença do Espírito e é impulsionada por ele. O Espírito a renova em sua comunicação com Cristo. O Espírito derrama sobre ela a força da nova criação, sua liberdade e sua paz (MOLTMANN, 1978, p. 12. Grifos do autor).

Este confronto da Igreja com a modernidade é o que desafia o fato de ser cristão no mundo de hoje. ${ }^{15}$ É um dos grandes desafios da esperança cristã. Tal situação nos desafia na questão de olhar para o outro, tido como desconhecido, obrigando-nos a nos colocar agora como próximo e ver assim a dimensão do Eu e do Tu. É uma comunicação indispensável para o confronto

13 O Concílio Vaticano II fundamentou isso de maneira específica: "A Igreja peregrina é por natureza missionária. Nasce, segundo o desígnio divino, da própria missão do Filho e do Espírito Santo" (Decreto Ad gentes n. 2, VATICANO II, 1998). Também: "Como toda a Igreja é missionária e o povo de Deus tem por função fundamental evangelizar" (Decreto Ad gentes n. 35, VATICANO II, 1998). A partir deste ponto, observamos que qualquer diálogo aproximativo com a Teologia da Esperança pode ser feito a partir do conceito de missão (missio), que é pelo qual a Igreja, comunidade de fé e esperança, projeta-se para o futuro, para o éschaton absoluto.

14 Não existe tradução em português desta obra. A indicação de mais fácil acesso está em espanhol: MOLTMANN, 1978.

15 Sobre este confronto da Igreja com a modernidade e o locus theologicus da esperança neste tempo, indicamos a obra: MOLTMANN, 1999.

Rev. Pistis Prax., Teol. Pastor., Curitiba, v. 1, n. 2, p. 443-467, jul./dez. 2009 
que vive hoje a esperança cristã (MOLTMANN, 2005, p. 392). Entendemos por este confronto toda a contradição que existe entre a cruz e a ressurreição, entre aquilo que $j a ́$ foi prometido e o presente ainda não realizado. Trata-se do conteúdo do amor ágape, que faz o cristianismo agir, em qualquer época, conforme a vontade de Cristo. Diz Moltmann:

Se o cristianismo quer e deve ser outra coisa, segundo a vontade de Cristo, em quem crê e a quem espera, deve tentar nada menos do que irromper para fora desses papéis sociais fixados. Deverá mostrar um comportamento não conforme os papéis que lhe são designados. Eis o conflito que é imposto a cada cristão e a cada pastor. Se o Deus, que os chamou à vida, espera deles outra coisa do que a sociedade industrial espera e exige, então o cristianismo deve ousar enfrentar o êxodo e ver os seus papéis sociais como um novo cativeiro babilônico. Somente quando ele aparecer como grupo que, do ponto de vista social, não se adapta perfeitamente e é incapaz de se adaptar; somente quando a integração moderna de todos em todos fracassar perante ele, só assim se defrontará com esta sociedade, em uma rivalidade carregada de conflito, mas frutuosa. (MOLTMANN, 2005, p. 403).

Esta ação do cristianismo - que ele já aponta em 1964 - se dá de modo diferente agora, o que leva o nosso autor a apontar para isso em uma reflexão que faz de sua Teologia da Esperança em 2008 durante sua passagem pelo Brasil: “o fim do cristianismo e o renascimento da Igreja” (MOLTMANN, 2008, p. 34). Sem dúvida é uma frase forte, contudo tem os seus fundamentos. Ele aponta para um fim porque o modo como o cristianismo se apresentou e se apresenta na sociedade nem sempre foi e é condizente com a Verdade que o sustenta. Atualmente vemos que o cristianismo não confronta o mundo, o mundo já não o assusta e não o questiona. ${ }^{16} \mathrm{O}$ que a Igreja diz (enquanto cristianismo -

16 Afirmamos, porém, que existem grupos cristãos que procuram fazer este enfrentamento e dar uma resposta aos problemas humanos. O movimento ecumênico é uma prova disso, como também às diversas campanhas de solidariedade, como no exemplo do Brasil, a Campanha da Fraternidade, etc. Um grande desafio para a Igreja é sentir-se parte do mundo e não mais a parte. Numa entrevista reservada com Moltmann na Universidade Metodista de São Paulo, ouvi-o falar que os católicos deveriam observar mais os avanços do Concílio Vaticano II, principalmente da Gaudium et spes, que diz que as alegrias e as tristezas do mundo são também as alegrias e as tristezas da Igreja. Sobre este assunto, indicamos uma outra obra do autor MOLTMANN, 1990.

Rev. Pistis Prax., Teol. Pastor., Curitiba, v. 1, n. 2, p. 443-467, jul./dez. 2009 
religião global) não causa tanto impacto na vida das pessoas, uma vez que estas descobriram que podem viver num mundo, que ainda é marcado pela cultura cristã, sem necessariamente ter de ser cristãs. Por isso Moltmann diz que o futuro da igreja é mais do que igreja, seu futuro deve se basear na novidade do ressuscitado e na força do Espírito que a conduz. Neste caso, precisa-se mais do que nunca de uma teologia do apostolado, voltada obrigatoriamente para o projeto do Reino de Deus (MOLTMANN, 2008, p. 35-36). Ressaltamos que esta intenção também apareceu na Conferência de Aparecida em 2007 (discípulos-missionários). ${ }^{17}$

Se olharmos juntamente com o autor por esse prisma, podemos acreditar que a única força capaz de manter a missão de forma livre e em andamento é a esperança. Ela que vai sustentar a Verdade da fé cristã para além do cristianismo. Ela procurará dar respostas àquilo que é a sua essência, que como vimos acima, é puramente escatologia, logo, esperança. Com efeito, toda essa espera e projeção terá como horizonte último - éschaton - a espera pelo Reino de Deus.

\begin{abstract}
O “cristianismo” tem sua essência e seu fim não em si mesmo e na própria existência, mas vive de alguma coisa, e existe para alguma coisa, que alcança muito além dele. Caso se queira compreender o mistério de sua existência e de suas formas de comportamento, necessário se faz perguntar pela sua missão. Caso se queira descobrir sua essência, é preciso perguntar pelo futuro em que ele coloca suas esperanças e expectativas. E se o cristianismo se tornou inseguro e sem orientação em meio às novas relações sociais, é preciso perguntar, mais uma vez, sobre a razão por que existe e o fim para o qual caminha. (MOLTMANN, 2005, p. 404, grifo do autor).
\end{abstract}

Certamente a razão para qual o cristianismo caminha não deve ser algo distante da sociedade em que ele está inserido. Ao contrário toda a sua força encontra-se em ser fermento no meio da massa, em ser contradição diante daquilo que é apresentado como definitivo e concreto. O olhar do cristão pertence ao mundo, mas projeta-se para fora do mundo, à procura do éschaton. Moltmann dirá que, “os cristãos que seguem a missão de Cristo, seguem igualmente a Cristo no serviço do mundo” (MOLTMANN, 2005, p. 407).

17 Ver CELAM, 2007.

Rev. Pistis Prax., Teol. Pastor., Curitiba, v. 1, n. 2, p. 443-467, jul./dez. 2009 
Isso é o que caracteriza a missão da Igreja e por isso ela é uma comunidade do êxodo. "Ela é comunidade de Deus quando é comunidade para o mundo" (MOLTMANN, 2005, p. 407). Este serviço que ele aponta em sua teologia é reforçado por ele hoje ao dizer que toda esta esperança deve ser desenvolvida por amor à vida, a vida humana e a vida de toda a terra. Nossa missão é destinada a contribuir na construção do Reino para este mundo. É o que se espera na ressurreição, onde Deus fará nova todas as coisas (Ap 21,5) (MOLTMANN, 2008, p. 35-37).

Isso não significa outra coisa a não ser uma Igreja orientada para o Reino de Deus. Esse Reino acontece quando a Igreja, na esperança do seu futuro com Cristo, transmite concretamente na sociedade uma prática de justiça, vida, humanidade e sociabilidade e, em suas decisões históricas evoca o futuro prometido. Ela não é em si mesma a salvação do mundo, mas está a serviço desta salvação, pois indica ao mundo o seu futuro. Ela é sinal e sacramento, como bem apresentou o Concílio Vaticano II, na Constituição Lumen gentium.

É o que Moltmann chama de vocação do cristianismo na sociedade (MOLTMANN, 2005, p. 410), quando este não se conforma com este mundo e procura transformá-lo através da resistência, baseado na imagem que crê, espera e ama (fé, esperança e amor). Isto resulta do chamamento de todos os cristãos, que conforme o NT é único, irrevogável e imutável. É Deus que nos chama à santidade e nos convoca para uma missão no mundo (MOLTMANN, 2005, p. 414). Trata-se, especificamente, da missão da esperança cristã.

Portanto, aceitar essa missão é ter esperança em algo melhor para a própria vida, É externá-la para que abranja a todos. É não se conformar, mas se inconformar. É viver inquieto na espera que um dia o éschaton prometido venha e complete toda a existência (1Cor 15,28, CONSELHO EPISCOPAL LATINOAMERICANO, 2007). Tal atitude nos leva, segundo o autor, a um seguimento criativo e a um amor criativo (MOLTMANN, 2005, p. 416). Estas expressões trazem comunhão e correspondem significativamente a todas as esperanças humanas, pois não se trata de uma expectativa passiva, mas de uma esperança cristã, uma esperança ativa. "A vida humana deve ser engajada caso queira ganhá-la. É preciso que ela se exteriorize se quiser consistência e futuro” (MOLTMANN, 2005, p. 419).

Assim, o caminho da esperança cristã que Moltmann apresenta na Teologia da Esperança nos faz ter um olhar para o futuro, mas, de certa 
forma, fixo na certeza revelada por Deus no passado (suas promessas). É certo que toda a ação da Igreja projeta-se hoje numa missio futura, a ponto de inserida na sociedade ela seja de tal modo um sinal concreto e vivo do amor de Deus por toda a humanidade. O caminho que apresenta hoje a esperança para inserir-se é um caminho ancorado na experiência e na espiritualidade. É um novo momento, diferente da década de 60 onde foi escrita. Isso é o que aponta a promessa e é o que deve fazer a comunidade do êxodo (Igreja). $\mathrm{O}$ autor nos remete às consequências de uma escatologia cristã (Konsequenzen einer christlichen Eschatologie), que conforme suas palavras destinam-se à missio de toda a Igreja presente na sociedade. Esta é a esperança que percorre a sua obra e que completa 45 anos, ainda com um futuro impensável.

\section{Conclusão}

Concluímos este artigo afirmando que a história, o caminho e a esperança que a Teologia da Esperança de Jürgen Moltmann percorreu nestes seus 45 anos tem características peculiares. Em sua trajetória pelo universo teológico ela libertou pessoas, abriu discussões e conflitos, esteve presente em meio a cristãos e não-cristãos, em meios teológicos e não-teológicos. Ou seja, ela percorreu uma história, um caminho e uma esperança só dela. Contudo, estas situações perduram porque se fundamenta em algo maior, cuja limitação humana não torna possível. Esta obra parte da esperança que foi depositada por Deus em seu povo, através de suas promessas, tornando-se sinal concreto no Cristo ressuscitado. É Deus que se revela oferecendo esperança. Acreditamos que esta é a chave de interpretação de sua teologia. A esperança que nasce deste fundamento diz que o mundo ainda não está concluído, mas que está em processo histórico, rumo ao éschaton absoluto. É o mundo do possível, no qual deve existir a verdade, a justiça e a paz. A Teologia da Esperança fala do horizonte de um futuro novo, que irrompe a partir de Cristo com destino à plenitude de tudo o que existe. Após 45 anos podemos dizer que o novo ainda está por vir. É o destino da esperança, que aguardamos ansiosamente e com fé. Por fim, é necessário concordar com WD. Marsch que, em 1972, ao escrever sobre a Teologia da Esperança, citou o famoso texto latino: "Os livros têm os seus destinos". 


\section{Referências}

BOFF, L. Índole escatológica da igreja peregrinante. Atualidade Teológica, Rio de Janeiro, ano 7, n. 13, p. 9-31, 2003.

CALVINO, J. Comentário sobre Hebreus 11,1. In: MOLTMANN, J. Teologia da esperança: estudos sobre os fundamentos e as conseqüências de uma escatologia cristã. São Paulo: Loyola, 2005. p. 33.

. Institutio, III2, 42. In: MOLTMANN, J. Teologia da esperança: estudos sobre os fundamentos e as conseqüências de uma escatologia cristã. São Paulo: Loyola, 2005. p. 35.

CONSELHO EPISCOPAL LATINO-AMERICANO - CELAM. Documento de Aparecida. São Paulo: Paulus, 2007.

GEYER, H-G. Acotaciones a la Telogía de la esperanza de Jürgen Moltmann. In: MARSCH, W-D.; MOLTMANN, J. Discusión sobre teología de la esperanza. Salamanca: Sígueme, 1972. p. 71-81.

GIBELLINI, R. La teologia di Jürgen Moltmann. Brescia: Queriniana, 1975. A teologia do século XX. 2. ed. São Paulo: Loyola, 1998.

JONG, J. M. Teologia de la esperanza. In: MARSCH, W-D.; MOLTMANN, J. Discusión sobre teologia de la esperanza. Salamanca: Sígueme, 1972. p. 41-81.

KUZMA, C. Da esperança à teologia da esperança: uma reflexão sobre o caminhar da esperança cristã em Jürgen Moltmann. Caminhando, São Bernardo do Campo, v. 13, n. 22, p. 11-20, 2008.

MARTINI, N. L'indole escatologica della chiesa peregrinante e sua unione con la chiesa celeste nella costituzione conciliare "Lumen gentium". Brescia: Morcelliana, 1972.

MARSCH, W. D.; MOLTMANN, J. Discusión sobre teología de la esperanza. Salamanca: Sígueme, 1972.

MOLTMANN, J. Temas para una teología de la esperanza. Buenos Aires: La aurora [19-?]. 
. Theologie der Hoffnung: Untersuchungen zur Begründung und zu den Konsequenzen einer christlichen Eschatologie. München: Chr. Kaiser Verlag, 1968 [1964].

El Dios crucificado: la cruz de Cristo como base y critica de toda teologia cristiana. Salamanca: Sígueme, 1977.

La Iglesia fuerza del Espiritu: hacia uma eclesiología mesiánica. Salamanca: Sigueme, 1978.

. La giustizia crea futuro: una politica ispirata alla pace e un’etica fondata sulla creazione in un mondo minacciato. Brescia: Queriniana, 1990.

. My theological career. In: . History and the triune god: contributions to trinitarian theology. Londres: SCM Press, 1991.

. Biografia e teologia: itinerari di teologi. Brescia: Queriniana, 1998.

. Dio nel progetto del mondo moderno: contributi per uma rilevanza pubblica della teologia. Brescia: Queriniana, 1999.

. Experiências de reflexão teológica: caminhos e formas da teologia cristã. São Leopoldo, RS: UNISINOS, 2004.

- Teologia da esperança: estudos sobre os fundamentos e as conseqüências de uma escatologia cristã. São Paulo: Loyola, 2005.

. Vida, esperança e justiça: um testamento teológico para a América Latina. São Bernardo do Campo, SP: Editeo, 2008.

MONDIN, B. As teologias do nosso tempo. São Paulo: Paulinas, 1979.

. Os grandes teólogos do século vinte. São Paulo: Teológica; Paulus, 2003. 
TAMAYO, J. J. Escatologia cristã. In: SAMANES, C. F.; TAMAYOACOSTA, J-J. (Dir.). Dicionário de conceitos fundamentais do cristianismo. São Paulo: Paulus, 1999. p. 223-234.

VATICANO II. Mensagens, discursos e documentos. São Paulo: Paulinas, 1998.

Recebido: 20/04/2009

Receveid: 04/20/2009

Aprovado: 02/05/2009

Approved :05/02/2009

Revisado: 15/07/2009

Reviewed: 07/15/2009 